\title{
A Website-based Information System Design of SME Development Facilitation Registration
}

\section{Perancangan Sistem Informasi Pendaftaran Fasilitasi Pembinaan IKM Berbasis Website}

\author{
Received: \\ 16 December 2020 \\ Revised: \\ 20 July 2021 \\ Published: \\ 8 August 2021
}

\author{
${ }^{1}$ Iman Sudirman, ${ }^{2}$ Indryati Sunaryo, ${ }^{3 *}$ Atya Nur Aisha, ${ }^{4}$ Joe \\ Monang, ${ }^{5}$ Illham Reza Prasetyo \\ 1,2,3,4,5 Program Studi Teknik Industri, Institut Teknologi Bandung, \\ Bandung \\ ${ }^{3}$ Program Studi Teknik Industri, Universitas Telkom, Bandung \\ E-mail: 'imansudirman_itb@yahoo.com, ${ }^{2}$ rya_ryo@yahoo.com, \\ ${ }^{3}$ atyanuraisha@gmail.com, ${ }_{4}^{4}$ joemonang@gmail.com, \\ ${ }^{4}$ ilhamrezaprasetyo@gmail.com
}

*Corresponding Author

\begin{abstract}
Small and medium enterprises (SMEs) are particularly important for the economy of West Java Province. Accordingly, The Industry and Trade Agency of West Java Province has conducted a number of facilitation programs to support the development of these SMEs. Neverheless, the implementation of facilitation programs is faced with some major problems, for example, the registration system for applying and proposing facilitation programs is still manually managed. As a result, some SMEs do not have the opportunity to propose and receive facilitation programs from the agency in addition to the several serious issues encountered by the agency to evaluate the facilitation programs. This study aims to design a website-based information system of SME development facilitation registration in the Industry and Trade Agency of West Java Province Government, Indonesia. It used the Waterfall method to develop the system. The results suggested that the system can well run as expected. In addition, the result of usability test indicates that the proposed system can be classified as acceptable because its score is 80.4 .
\end{abstract}

Keyword - Information system, SME, Waterfall

Abstrak - Industri kecil dan menengah (IKM) sangat penting bagi perekonomian Jawa Barat. Oleh karena itu, Dinas Perindustrian dan Perdagangan Pemerintah Provinsi Jawa Barat (Disperindag Jabar) telah menyelenggarakan berbagai program fasilitasi untuk mendukung perkembangan IKM. Akan tetapi, pelaksanaan program fasilitasi dihadapkan pada beberapa masalah penting, misalnya, sistem registrasi untuk mengajukan dan mengusulkan program fasilitasi masih dikelola secara manual. Akibatnya, beberapa IKM tidak memiliki kesempatan untuk mengusulkan dan mendapatkan program fasilitasi dari Disperindag Jabar, selain beberapa isu penting yang dihadapi Disperindag Jabar dalam mengevaluasi program fasilitasi. Penelitian ini bertujuan untuk merancang sistem informasi pendaftaran fasilitasi pembinaan IKM berbasis website di Dinas Perindustrian dan Perdagangan Pemerintah Provinsi Jawa Barat, Indonesia. Metode yang digunakan untuk mengembangkan sistem informasi adalah Waterfall. Hasilnya menunjukkan bahwa sistem dapat berjalan sesuai dengan yang diharapkan. Selain itu, hasil uji usabilitas mengindikasikan bahwa sistem yang diusulkan termasuk dalam kategori "dapat diterima" karena nilai skor usabilitas adalah 80,4.

Kata Kunci-Sistem informasi, IKM, Waterfall 


\section{INTRODUCTION}

The role of small and medium industries (SMEs) in the West Java economy is very important. In 2017, the number of SMEs in West Java Province reached 213,291 business units, with an average annual increase of $1.19 \%$ during the $2012-2017$ period. In the same year, the investment value from SMEs reached 582 trillion Rupiah and its absorption of employment reached 5.48 million people [1].

The Industry and Trade Agency of West Java Province (Disperindag Jabar hereafter) have carried out such various development facilitation programs as promotion and marketing for SME's products, in order to support the growth and development of SMEs in the West Java Province. However, in implementing these facilitation programs, Disperindag Jabar has encountered several major problems. One of which is the registration system of development facilitation is manually operated. District/city governments submit applications or proposals for the facilitation programs of SMEs to the Disperindag Jabar through written letters. Then, the Disperindag Jabar follows up the request and decides whether these applications or proposals are approved or not. Afterwards, the Disperindag Jabar records the data of those SMEs that have obtained the facilitation programs in the Microsoft Excel. These data are managed by several different divisions. There are at least three negative impacts resulting from this manual registration system: 1) not every SME gets the opportunity to propose and obtain development facilitation from the Disperindag Jabar, b) there is an opportunity for the Disperindag Jabar to repeatedly provide development facilitation to the same SME, and c) there are difficulties for the Disperindag Jabar to evaluate the facilitation program that have been provided as the required data are not sufficiently available. As underlined by [2], an information system that are operated manually can increase work-time load, extend information retrieval process time and intensify the likelihood of loosing important data.

These negative impacts can be resolved by developing a website-based information system that is intended to facilitate SME in the registration process. This kind of information system can provide an easy access for SMEs as targeted users to propose and fulfill their needs [3] and make it easier for Disperindag Jabar in collecting and reporting data related to SMEs [4]. In addition, the information system can also be integrated with other information systems in the Disperindag Jabar, such as databases for SMEs. Moreover, as digital era governance is a growing trend in the field of public services [5], citizens expect the government to increasingly use recent technology for improving government-citizens interaction to increase social values [6]. Thus, it will support the evolution in the modernization of public service activities by the government to the latest stage, i.e. online-based public services [7]. 
INTENSIF, Vol.5 No.2 August 2021

ISSN: 2580-409X (Print) / 2549-6824 (Online)

DOI: https://doi.org/10.29407/intensif.v5i2.15399

The study aims to design a website-based information system of SME development facilitation registration in the Disperindag Jabar. Several studies have tried to design information systems for SMEs. However, to the best of our knowledge, there has not been any research focusing on designing an information system of development facilitation for SMEs in Indonesia (see Table 1). This study is different from previous research in two aspects. Firstly, the object of our study is SMEs that are assisted by the Disperindag Jabar spreading over 27 districts/cities. To the best of the author's knowledge, research for designing an information system of facilitation registration for SMEs under assistance of Disperindag Jabar has not been conducted. Secondly, we acknowledge that several previous studies has also used the same method as this study (the waterfall method) to develop the systems, but the features of the systems, to some extent, are relatively different. This is understandable because the features developed in the systems are dependent on the focus of the problems to be solved.

Table 1. SEVERAL PREVIOUS STUDIES RELATED TO APPLICATION DESIGN FOR SMES INFORMATION SYSTEM

\begin{tabular}{|c|c|c|c|}
\hline Authors & Output & Method & Object \\
\hline [3] & $\begin{array}{l}\text { Web-based information } \\
\text { system design for } \\
\text { "Koperasi" data collection }\end{array}$ & Waterfall & $\begin{array}{l}\text { Koperasi business } \\
\text { unit in Ternate }\end{array}$ \\
\hline [4] & $\begin{array}{l}\text { Information system design } \\
\text { for hospital management } \\
\text { with focus on facilities and } \\
\text { infrastructure modules }\end{array}$ & $\begin{array}{l}\text { Total Architecture } \\
\text { Synthesis (TAS) }\end{array}$ & $\begin{array}{l}\text { Hospital of } \\
\text { Universitas Udayana }\end{array}$ \\
\hline [8] & $\begin{array}{l}\text { E-commerce creative } \\
\text { industrial product design in } \\
\text { the context of SMEs }\end{array}$ & $\begin{array}{l}\text { System requirement } \\
\text { analysis, system } \\
\text { design and } \\
\text { application }\end{array}$ & $\begin{array}{l}\text { SMEs in the city of } \\
\text { Serang }\end{array}$ \\
\hline [9] & $\begin{array}{l}\text { Geographical information } \\
\text { system design for seeking } \\
\text { SMEs location }\end{array}$ & Waterfall & SMEs in Jepara \\
\hline$[10]$ & $\begin{array}{l}\text { Management information } \\
\text { system design for SMEs } \\
\text { data collection }\end{array}$ & Waterfall & SMEs in Sragen \\
\hline
\end{tabular}

Theoretically, an information system is a collection of interrelated components that collect or retrieve information, then process, store, and distribute it. This information is used as the basis for decision making, coordination, control, and various kinds of complex problem-solving activities in an organization. An information system processes the information it collects through four stages of input, process, output, and feedback [11]. In general, the information collected in an information system is data that come from various and scattered sources. With the advancement of technological developments, the information processing process can be performed in a more expeditious manner using information systems. It results in a quicker 
process of decision making, coordination, and other activities in an organization as well as increasing accuracy and providing measurable output [12].

Rapid developments in the field of information technology also bring new trends in the implementation of information systems. Massive increased in the capability of computer and the fast development of IoT has bridged human, data, and things [13]. The ubiquitous of smart phones has made access to information technology becoming more widespread [14]. As a result, information system is a must for an organization to be able to survive and compete in this day and age.

There are three dimensions in information systems, which are organization, management, and technology. The organizational dimension describes the goals to be achieved and the structure that describes how the organization divides its resources to achieve these goals. The management dimension describes how an organization deals with various decisions, plans, and actions in solving organizational problems. These two dimensions need to be considered and reconciled with existing technology so that the information system is developed based on the character of the organization [11]. Moreover, there are at least 6 main components in an information system [14], which are:

1. Data: inputs are used by an information system to produce information.

2. Hardware (hardware): computer and its components.

3. Software (software): a set of instructions that tell the computer how the data is processed.

4. Telecommunication: software and hardware that are useful for facilitating the transfer of information in the form of electronic data.

5. Human: users who design information systems in order to help the organization perform its activities.

6. Procedure: rules so that data can be processed optimally and safely.

Organizations must continue to pay attention to these six components so that their information systems can continue to work optimally. The features in the information system also need to be updated periodically and the capabilities from the human aspect need to be continuously improved so that the capabilities of the information system can continue to be developed [15].

Although there are various methods that can be used when developing an information system, the System Development Life Cycle (SDLC) is one of the methods that is widely used [15] [16] [17]. The SDLC is also known as the "waterfall" approach because it consists of sequential steps. This model has also been widely used in designing information systems applications in various sectors in Indonesia [18]

The first stage in SDLC is the system analysis. In this stage, the information system currently underway is investigated to assess whether the net benefit of the system is still greater than the 
INTENSIF, Vol.5 No.2 August 2021

ISSN: 2580-409X (Print) / 2549-6824 (Online)

DOI: https://doi.org/10.29407/intensif.v5i2.15399

cost of managing the information system or whether there are other information system alternatives that have a greater net benefit. This stage is followed by a feasibility analysis from a technical, financial, and operational perspective. If the new information system is considered feasible from these three points of view, then the system requirements are drawn up. The system requirements are then used as the basis for the system design stage. In this stage, the information system design is communicated using two concepts, namely Data Flow Diagrams (DFD) and Unified Modeling Language (UML).

DFD is a structured approach that describes the flow of data contained in an organization's business processes [19]. DFD uses 4 elements to describe the data flow. The four elements are the entity, data flow, process, and data storage. DFD has several levels. Upper-level DFD is intended to be understood by organizational members without specialized knowledge in the field of information technology while low-level DFD has a deeper technical content so it is intended for more technical organization members [14].

UML is used to communicate the software that is being designed. UML uses a variety of standard symbols to visualize the features and logic of an information system, regardless of the programming language used to develop the information system [20]. The information system design that has been created is then developed and tested to ensure that the information system created is feasible and reliable.

The next stage of the SDLC is the implementation stage which is divided into the conversion and training process. The conversion process takes place to convert the information system currently in the new developed information system. Organization members are then trained to use this information system. The SDLC stage is concluded with the support stage for the information system that has been implemented to maintain its performance [14].

\section{RESEARCH METHOD}

This study uses the Waterfall as the system development method. According to [21], the systematic stages in software development with this method consist of identifying user needs, system modeling, software development, and implementation. The stages of the research carried out are referred to the stages in the Waterfall method as shown in Figure 1.

In the first stage, various relevant information is collected for the development of the registration information system. Series of interviews with the Disperindag Jabar were conducted to discuss the scope of the information system required as well as literature review to look for relevant previous studies. There are five previous studies that discussed the development of the 
SMEs information system in Indonesia (refer to Table 1). Each study was conducted based on different needs, adapted to the characteristics of users in each region.

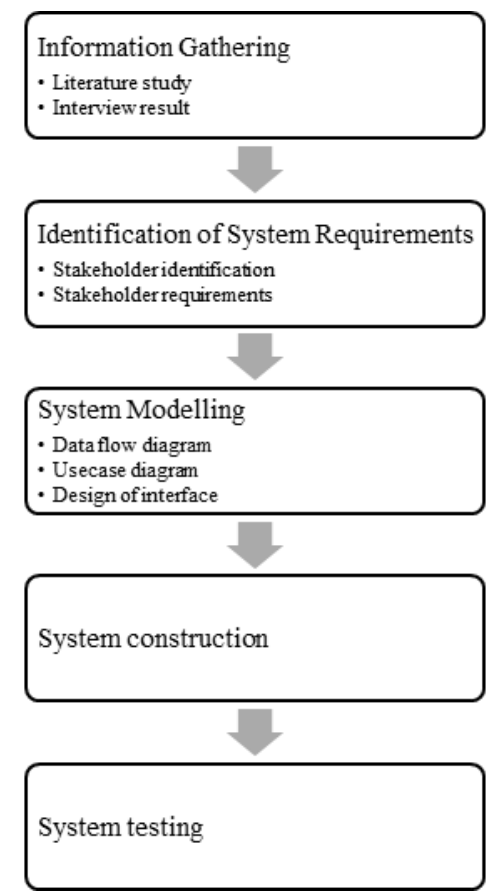

Figure 1. SYSTEM DEVELOPMENT STAGES

The second stage is to identify the information system requirements based on various information collected from the previous stage. Identification of needs begins with determining the relevant stakeholders who will be the users of the system. Identification of needs is a critical process in software development, because it determines the quality and success of the developed software [22]. System modeling and design in the third stage is performed after information about the detailed needs of each user is obtained. Data flow diagrams and use case diagrams were used to model the system. Afterwards, the information system interface is designed.

The fourth stage is the coding process to develop the system using PHP programming language with the Laravel framework. The information system is developed in accordance with the system requirements identified from the previous stage. The last stage is conducting system testing which aims to test the system for verification and validation of system users. The system testing process uses a black box approach from various scenarios according to needs, such as in study [23]. The black box method was chosen because it aims to test the user experience in running the designed information system [24]. Moreover, based on [25]'s study, one of the commonly used software testing methods is the black box. Usability testing is also performed to find out whether the proposed system is suitable for use or not [26]. The detail of the proposed SMES database information system is as following. 
INTENSIF, Vol.5 No.2 August 2021

ISSN: 2580-409X (Print) / 2549-6824 (Online)

DOI: https://doi.org/10.29407/intensif.v5i2.15399

\section{A. Information Gathering}

Series of discussions were held with Disperindag Jabar, especially with the Planning and Program Subdivision. This initial discussion aims to explore the problems faced related to the existing registration process for the SMEs coaching and facilitation.

Several problems were identified regarding the registration process. Registrations were processed manually, beginning with information dissemination about facilitation activities by Disperindag. SMEs then registered by contacting Disperindag. Data of the registering SMEs then processed using Microsoft Excel and stored locally. Using this system, evaluation became difficult. SMEs were also not be able to receive a continuous development facilitation program because the data was not integrated. The development of an information system is expected to help and facilitate Disperindag Jabar to collect the data so that it is able to determine and design programs activities for the development of SMEs more precisely and quickly.

In addition, various studies related to development of information systems for SMEs management in various regions in Indonesia were also reviewed at this stage of development. The results of this literature study were used as additional input for the information system development, as well as reference for various features on the information system design.

\section{B. Identification of System Requirements}

The system needs were obtained from interviews with the Sub Division of Planning and Programs of Disperindag Jabar. The interview process identified several principal information such as stakeholders who will use the information system, the data that will be needed, the desired interface of the information system, and the expected features of the website-based information system.

Based on these results, stakeholders' needs were identified, both from the direct and the indirect users. These needs were listed as follow:

1. SMEs who will use the information system to fill in and edit the company profile, register development facilitation activities, and propose facilitation activities.

2. The roles of the agency are divided into two, as a Field Admin and Super Admin. The role of Field Admin will use the information system to verify data for the registered SMEs, add details to the development facilitation activities managed by the agency, register the attendance of the registered SMEs according to the development facilitation activities, obtain a recap of proposals for facilitating activities or development proposals from SMEs, and compile reports on development facilitation activities that have happened. The role of field admin will be held by representatives of each field who are determined by the respective Field Chairs. 
3. The Super Admin role is to use the information system to add a Field Admin account, add options for development facilitation activities that can be provided, and add fields that become group of development facilitation activities. The Super Admin role will be managed by the Sub Division of Planning and Programs of Disperindag Jabar.

\section{System Modelling}

The designed system model covers data flow diagrams and use case diagrams. Data flow diagrams are designed to describe the flow of data in the system. According to [27], the use of DFD in object oriented modeling aims to describe the overall function of the information system which in the use case diagram only describes the interface. The forementioned design of the developed registration information system is in Figure 2.

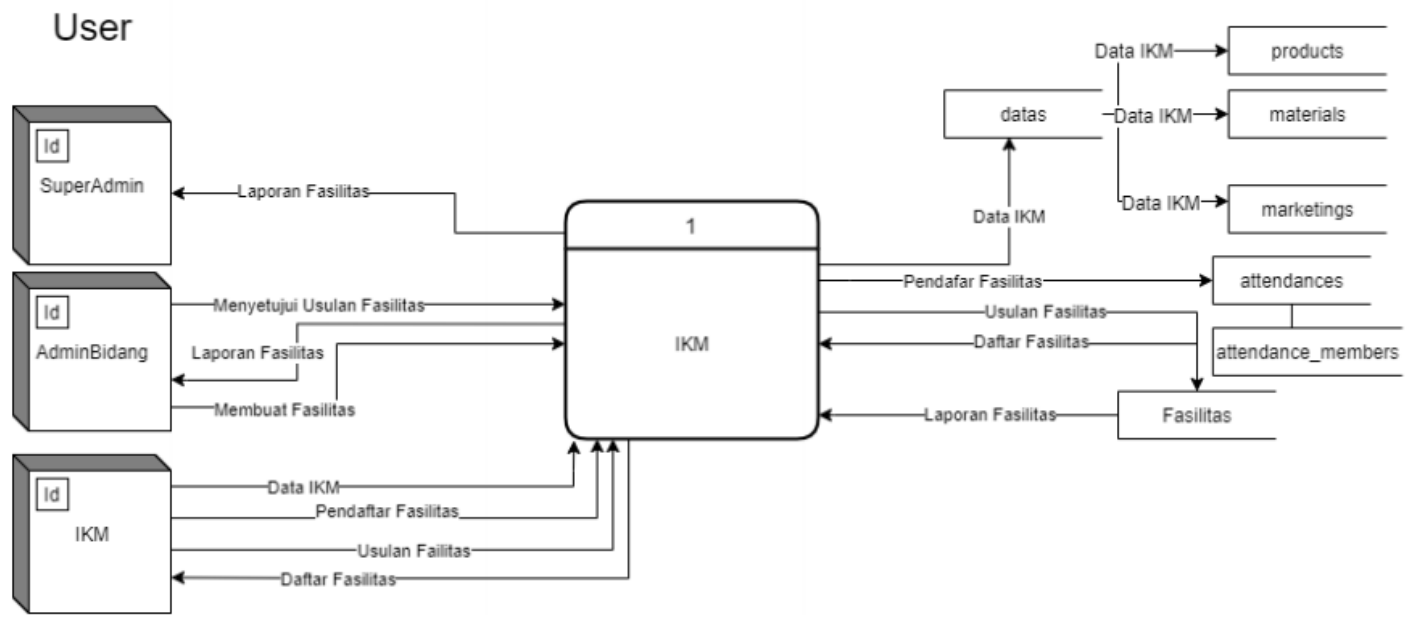

Figure 2. DATA Flow DiAgRAM DESIGN

Use case diagrams are designed to explain the relationship and needs of the user stakeholders, which are the SMEs, Field Admin and Super Admin. This model reflects the activity specifications of each user in the information system. Details for each activity performed by each user are described as follows:

For SMEs users, the activities include registering a new account, logging into the information system, filling in and editing the company profile, viewing the history of coaching facilitation that has been received, registering development facilitation activities, submitting development facilitation suggestions, and logging out of the system. These activities are reflected in the SMEs use case diagram in Figure 3. 
INTENSIF, Vol.5 No.2 August 2021

ISSN: 2580-409X (Print) / 2549-6824 (Online)

DOI: https://doi.org/10.29407/intensif.v5i2.15399

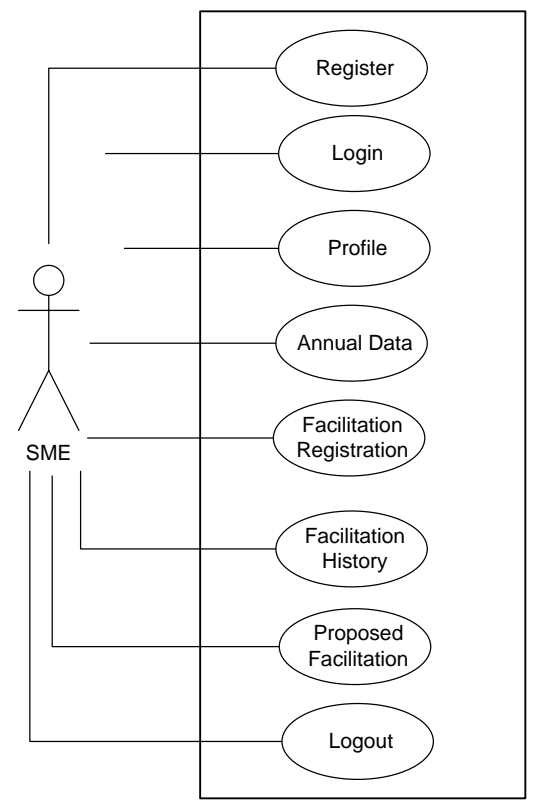

Figure 3. USE CASE DIAGRAM FOR SMES USERS

For Field Admin, the activities include logging into the information system, verifying SMEs that register in the information system, viewing and editing profiles of registered SMEs, adding details of development facilitation activities, listing the attendance of registered SMEs according to activities, compiling reports based on the implementation timeframe and data requirements, as well as logging out of the information system. Reports can be downloaded in Microsoft Excel format. The activities carried out are reflected in the Field Admin use case diagram in Figure 4.

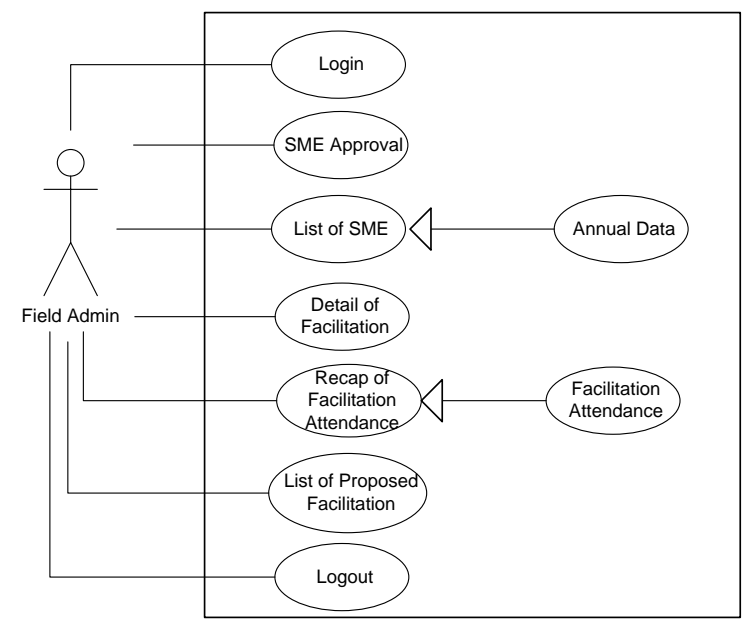

Figure 4. USE CASE DIAGRAM FOR FIELD ADMIN USERS

For Super Admin users, the activities include logging into the information system, adding and editing Field Admin account, adding and deleting the field/UPTD of SMEs trainer, adding and removing options for development facilitation activities for SMEs, and logging out of the information system. Figure 5 shows a use case diagram for Super Admin users. 


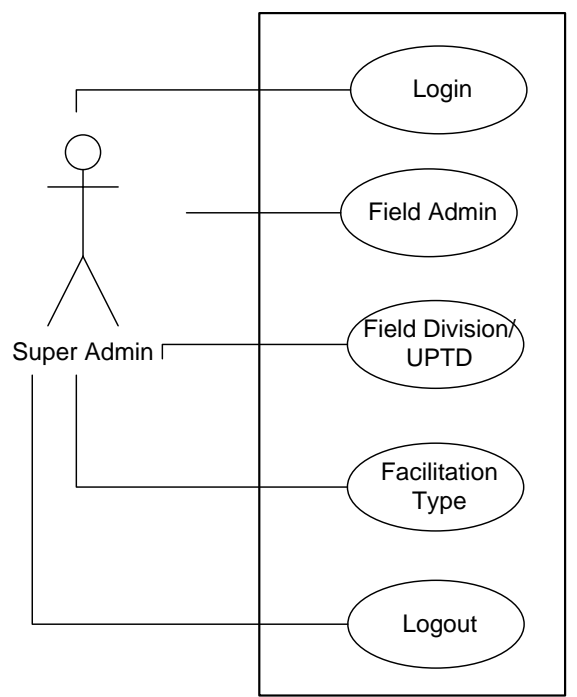

Figure 5. USE CASE DIAGRAM FOR SUPER ADMIN USER

The overall scenario of the SMEs database information system begins with SMEs registering in the information system as a new user. Next, the Field Admin will verify the proposed SMEs data with a list of previous assisted SMEs. Admin will proceed with the approval, and the SMEs will receive a notification and will be able to log into the system. If an SME has successfully logged in, then SME needs to fill in their company profile. SME that has completed the company profile will be able to register for development facilitation activities according to the available sessions. If the development facilitation that are needed by SMEs are unavailable, SMEs can propose the new ones. The data of the registered SMEs will then be listed by the Field Admin to be included in as the participants in the development facilitation activities. After the activity is completed, the Field Admin can fill in the attendance list. The Field Admin can also collect the development facilitation proposals submitted by the SMEs. At the end of the activities, the Field Admin can compile an activity report as well as any other required data.

The design of the interface in the information system is designed according to the input from Disperindag Jabar, obtained from the interviews. Some of the inputs regarding the interface display on information systems include:

1. Displaying the logo of the agency

2. Using orange color as the background for the interface

3. Not using image composition excessively.

After that, the coding process was carried out for the registration information system. This information system programming uses the PHP programming language and the Laravel framework. The database used is MySQL. 
INTENSIF, Vol.5 No.2 August 2021

ISSN: 2580-409X (Print) / 2549-6824 (Online)

DOI: https://doi.org/10.29407/intensif.v5i2.15399

\section{RESULT AND DISCUSSION}

This section discusses the display appearance of the registration information system that has been designed and developed. The available interfaces in the information system are tailored to the features required by each user in the information system.

Figure 6 shows the main page view of the information system. In the main page, there are a logo of Disperindag Jabar and the log in field. If the SME does not have an account, they can register by clicking the button "Register Now".

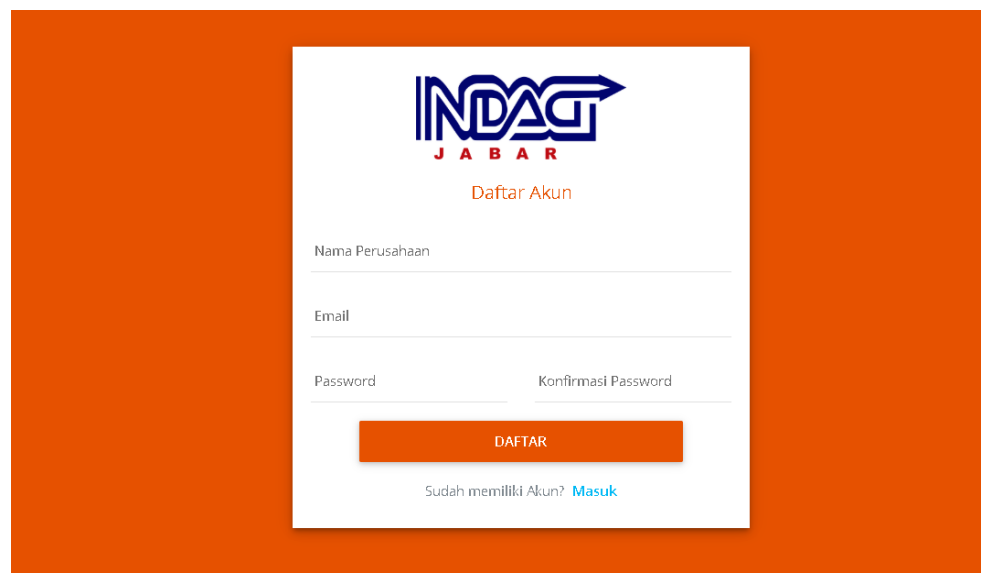

Figure 6. THE REGISTRATION PAGE

After an SME receives notification that their new account has been approved by the information system manager, which is the Field Admin, SME can log into the information system by using e-mail and their password. After successfully logging in, there are three main menus that can be accessed by SMEs. Those menus are "Edit Profile", "Add Annual SME Data", "Development Facilitation History", and "Development Facilitation Registration". SMEs need to fill in their company profile which includes the company name, company legal entity, owner's name, office and/or factory address, year of establishment, business group, coaching area, and contact information. After all the information has been filled in, users can finish the submission by clicking the save button.

SMEs need to fill in annual data related to their development, which includes the number of workers, types and quantities of raw materials, value of products, products produced, types of licenses, and market segment. After filling in this data, SME can apply to register for development facilitation activities carried out by Disperindag Jabar. Figure 7 shows the page view for filling in the registration form for SME development facilitation activities. 


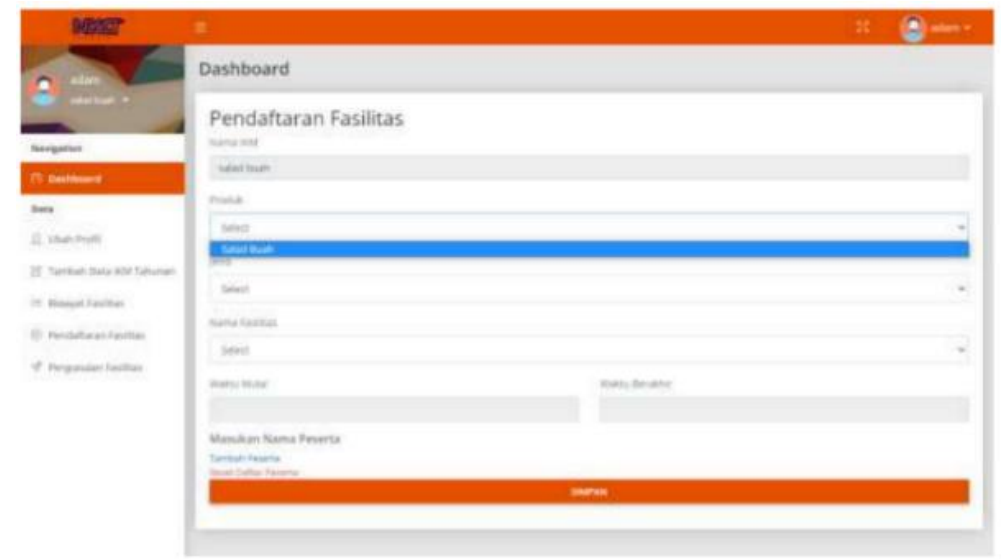

Figure 7. PAGE VIEWS OF THE REGISTRATION FOR DEVELOPMENT FACILITATION ACTIVITIES

Field Admin can log into the system using the account and password previously created by Super Admin. After successfully logging in, there are four main menus that can be accessed, that are "Approve SME", "List of SMEs", "Facility", and "Report Data". The purpose of "Approve SME" menu is for Field Admin to verify the registered SMEs with the list of SMEs under the guidance of Disperindag Jabar. In this menu, if the SMEs have never been under the guidance of Disperindag, the Field Admin has the right to reject the application. Figure 8 shows the page view of the "Approve SME" menu.

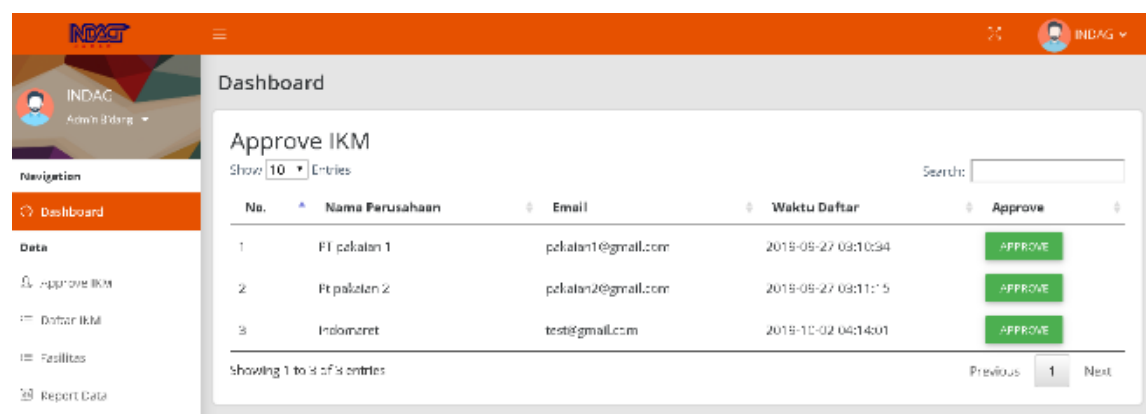

Figure 8. PAGE VIEW OF SME APPROVE MENU

After verification, the SME will be inputted to the database. The Field Admin can see the entire list of SMEs under the guidance of Disperindag Jabar that have registered and view various information related to the company profile and annual data of the SME. In addition, the Field Admin can also add and fill in details of the development facilitation activities under Disperindag Jabar's plan, including the title of the activity, the time of implementation, and the field of the organizer. In each activity, the Field Admin can add information related to activity participants from the registered SMEs. Participants may include the number and names of participants, as well as related products submitted for development facilitation activities. Figure 9 shows the display of the facility page. 
INTENSIF, Vol.5 No.2 August 2021

ISSN: 2580-409X (Print) / 2549-6824 (Online)

DOI: https://doi.org/10.29407/intensif.v5i2.15399

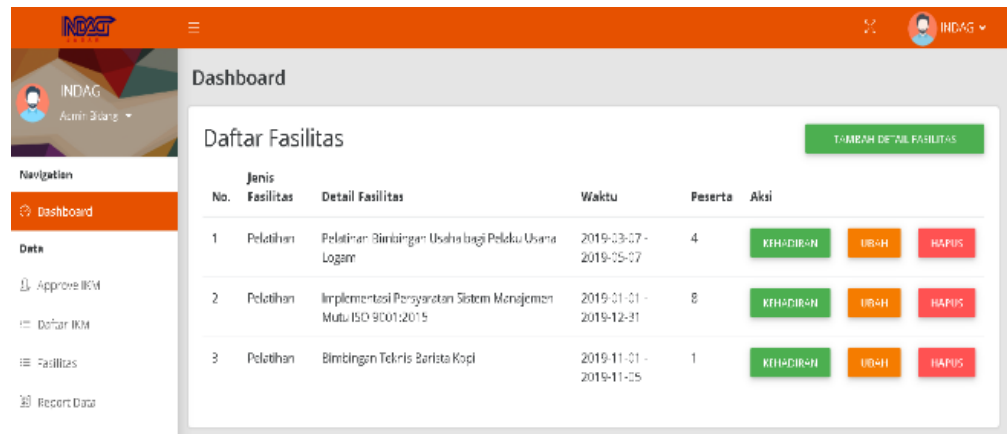

Figure 9. FACILITIES PAGE VIEWS ON THE FIELD ADMIN

Super Admin can log into the system using a predetermined password. After a successful login, there are three main menus that can be accessed by Super Admin users, that are "Field Admin", "Field/UPTD of Trainer", and "Type of Facility". In the "Field Admin" menu, there is a list of previously created Field Admin accounts. Password change and addition of new accounts can be accessed here as well. Figure 10 shows the page view of this menu.

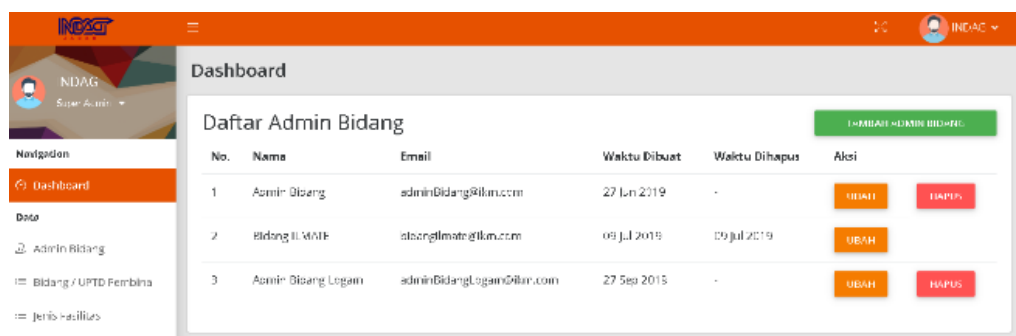

Figure 10. PAge VIEW OF Field AdMIN List PAGE ON SUPER AdMIN

After the development of this information system prototype, the next step is testing the information system on prospective users, namely Disperindag Jabar, especially the Planning and Program Subdivision. This testing is performed using the black box method related to several activities that can be managed in the information system. Table 2 shows the results of the testing step.

Table 2. RESUlT OF INFORMATION SYSTEM TESTING

\begin{tabular}{|c|c|c|c|c|}
\hline No & User & Tested Features & Result & Note \\
\hline 1 & SME & $\begin{array}{l}\text { Development facilitation } \\
\text { registration }\end{array}$ & Succeed & $\begin{array}{l}\text { Information system is } \\
\text { performing as expected }\end{array}$ \\
\hline 2 & Field Admin & $\begin{array}{l}\text { Filling in detail of } \\
\text { development facilitation } \\
\text { activities }\end{array}$ & Succeed & $\begin{array}{l}\text { Information system is } \\
\text { performing as expected }\end{array}$ \\
\hline 3 & $\begin{array}{l}\text { Super } \\
\text { Admin }\end{array}$ & $\begin{array}{l}\text { Adding type of } \\
\text { development facilitation }\end{array}$ & Succeed & $\begin{array}{l}\text { Information system is } \\
\text { performing as expected }\end{array}$ \\
\hline
\end{tabular}

Furthermore, usability testing is carried out which aims to determine whether the proposed system is suitable for use or not [25]. Usability testing was carried out through distributing questionnaires containing nine evaluation questions as shown in Table 3. There are 30 samples of 
INTENSIF, Vol.5 No.2 August 2021

ISSN: 2580-409X (Print) / 2549-6824 (Online)

DOI: https://doi.org/10.29407/intensif.v5i2.15399

respondents who are prospective users of the SME facility registration information system who are involved in usability testing.

Table 3. ITEM EVALUATION OF USABILITY TESTING

\begin{tabular}{ll}
\hline \hline Code & \multicolumn{1}{c}{ Item Evaluation } \\
\hline P1 & $\begin{array}{l}\text { The display design of the information system of SME facilitation registration (such as login } \\
\text { pages, dashboards, registrations, etc.) is uniform }\end{array}$ \\
P2 & $\begin{array}{l}\text { The overall design of the information system of SME facilitation registration (such as login } \\
\text { pages, dashboards, registrations, etc.) is easy to understand }\end{array}$ \\
P3 & $\begin{array}{l}\text { The menu on the information system of SME facilitation registration (such as approve facility } \\
\text { proposal, facility list, report data) is complete and adequate }\end{array}$ \\
P4 & $\begin{array}{l}\text { The menu on the information system of SME facilitation registration (such as approve facility } \\
\text { proposal, facility list, report data) is easy to find }\end{array}$ \\
P5 & $\begin{array}{l}\text { The information content displayed on the information system of SME facilitation registration is } \\
\text { complete }\end{array}$ \\
P6 & $\begin{array}{l}\text { The choice of color and contrast between the background and the text on the the information } \\
\text { system of SME facilitation registration is good }\end{array}$ \\
P7 & $\begin{array}{l}\text { By using the information system of SME facilitation registration, it will make it easier for me to } \\
\text { complete my work }\end{array}$ \\
P8 & $\begin{array}{l}\text { Overall, I am satisfied with the information system of SME facilitation registration } \\
\text { P9 }\end{array}$ I am willing to use the information system of SME facilitation registration for the work \\
\hline
\end{tabular}

The usability score calculation is obtained from the total usability score of the respondents' perceptions divided by the number of respondents. The usability score that shows a value of more than 70 is included in the "Acceptable" category [25]. Based on the calculations shown in Table 4, it shows that the average usability score is 80.4. These results indicate that the reusability score is included in the "Acceptable" classification. Thus, the proposed SMEs facilitation registration information system using the waterfall method is considered to have met the design requirements and can be used.

Table 4. Result OF UsABILITY TESTING

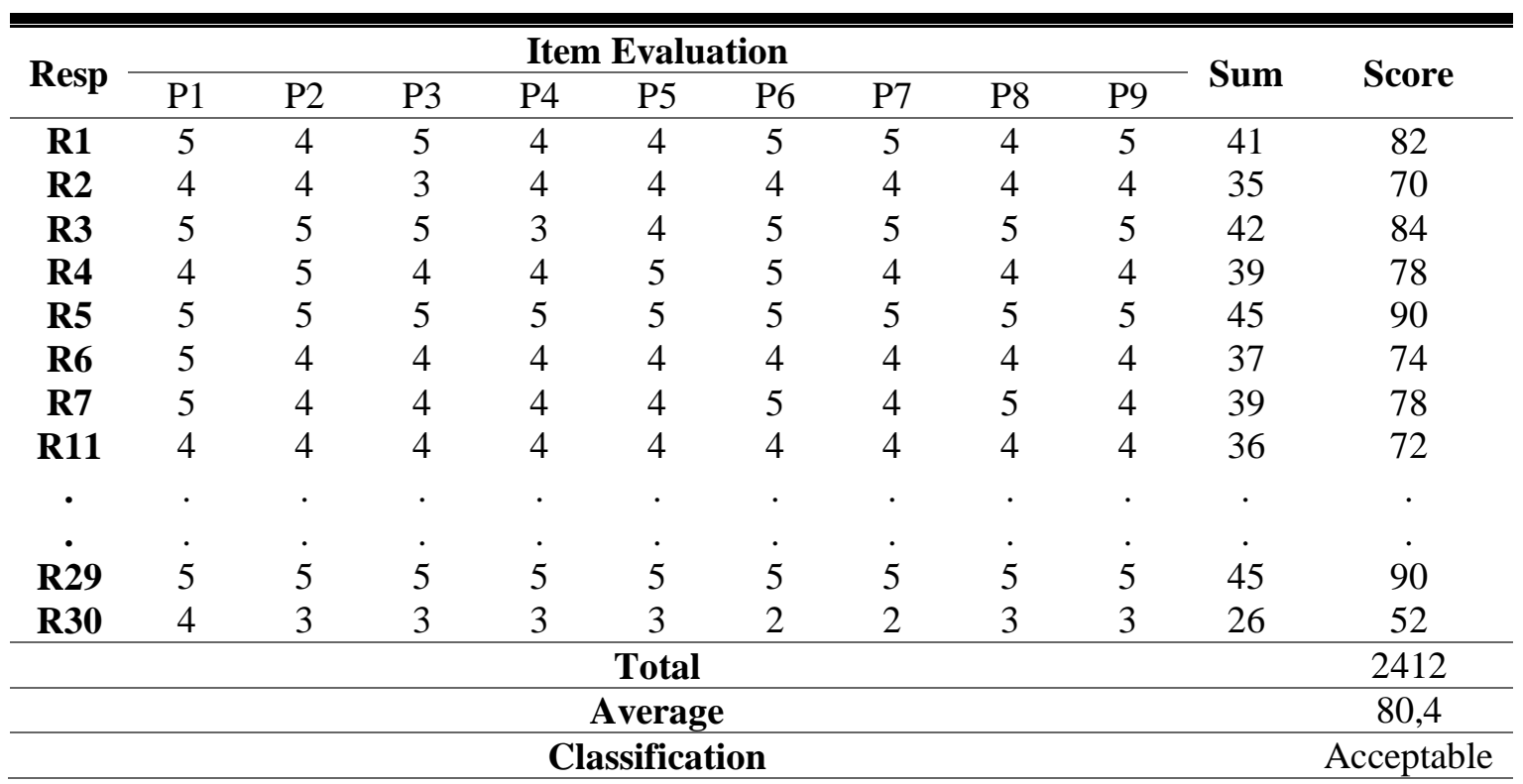

INTENSIF: Jurnal Ilmiah Penelitian dan Penerapan Teknologi Sistem Informasi 
INTENSIF, Vol.5 No.2 August 2021

ISSN: 2580-409X (Print) / 2549-6824 (Online)

DOI: https://doi.org/10.29407/intensif.v5i2.15399

\section{CONCLUSION}

This registration information system is designed to have several features such as data recording for SMEs, registration of development facilitation activities organized by Disperindag Jabar, and submission of relevant development facilitation proposals for SMEs. There are two stakeholders who will use this system, namely SMEs and Disperindag Jabar. SMEs will play the role of users. On the part of Disperindag Jabar, there are two roles that are exist, namely Field Admin and Super Admin. System modeling is performed using data flow diagrams and use case diagrams. The system testing step using black box method found that the information system can perform as expected. The usability testing results show that the usability score is included in the "Acceptable" classification. For Disperindag Jabar, the information system can be used to store data regarding development facilitation activities that have been carried out, make it easier to compile activity reports and conduct evaluations of the SME development facilitation activities.

\section{ACKNOWLEDGMENTS}

Financial support for this study was provided by a grant from the P3MI Program of Institut Teknologi Bandung.

\section{REFERENCES}

[1] Badan Pusat Statistik Provinsi Jawa Barat, Provinsi Jawa Barat Dalam Angka Tahun 2019, Bandung: BPS Provinsi Jawa Barat, 2019.

[2] D. H. Kusuma, M. N. Shodiq, D. Yusuf, and L. Saadah, "Si-Bidan: Sistem Informasi Kesehatan Ibu dan Anak," INTENSIF: Jurnal Ilmiah Penelitian dan Penerapan Teknologi Sistem Informasi, vol. 3, no. 1, pp. 43-53, 2019, doi: 10.29407/intensif.v3i1.12508.

[3] Rosihan dan S. Lutfi, "Pendataan Koperasi pada Dinas Koperasi dan UKM Kota Ternate berbasis Web", JIKO (Jurnal Informatika dan Komputer) Ternate, vol. 2 no. 1, 2018.

[4] A. A. I. A. D. Purnamaningrat, I. M. Sukarsa dan N. M. I. M. Mandenni, "Perancangan Sistem Informasi Manajemen Rumah Sakit Modul Sarana dan Prasarana", Lontar Komputer, vol. 6 no. 2, pp. 73-83, 2015.

[5] C. Greve, "Ideas in Public Management Reform for the 2010s. Digitalization, Value Creation and Involvement," Public Organizatino Review, vol. 15, no. 1, pp. 49-65, 2015, doi: 10.1007/s11115-013-0253-8.

[6] J. D. Twizeyimana and A. Andersson, "The public value of E-Government - A literature review," Government Information Quarterly, vol. 36, no. 2, pp. 167-178, 2019, doi: 10.1016/j.giq.2019.01.001.

[7] S. A. Chun, S. Shulman, R. Sandoval, and E. Hovy, "Government 2.0: Making connections between citizens, data and government," Information Polity, vol. 15, no. 12, pp. 1-9, 2010, doi: 10.3233/IP-2010-0205.

[8] Rizal, A. Bahauddin dan N. Ummi, "Perancangan E-Commerce IKM Produk Industri Kreatif Kota Serang", Jurnal Teknik Industri, vol. 1 no. 4, 2013.

[9] N. Azizah dan N. A. Widiastuti, "Implementasi Sistem Informasi Geografis Pencarian 
Lokasi UMKM di Kabupaten Jepara”, Informatika dan RPL, vol. 1 no. 1, 2019.

[10] E. Susena, A. Y. Ratnawati dan E. Susanto, "Analisis dan Perancangan Sistem Informasi Manajemen Pendataan Industri Kecil dan Menengah (SIM-IKM)", Jurnal AKSI (Akuntansi dan Sistem Informasi), vol. 4 no. 1, 2019.

[11] K. C. Laudon dan J. P. Laudon, Management Information Systems: Managing the Digital Firm, Global Edition. Pearson, 2017.

[12] Q. Duan, K. Chakrabarty, dan J. Zeng, Data-Driven Optimization and Knowledge Discovery for an Enterprise Information System, 2015, Springer International Publishing.

[13] A. Gupta, A. Deokar, L. Iyer, R. Sharda, and D. Schrader, "Big Data \& Analytics for Societal Impact: Recent Research and Trends," Information Systems Frontiers, vol. 20, no. 2, pp. 185-194, 2018, doi: 10.1007/s10796-018-9846-7.

[14] I. Quadir, "Form, Transform, Platform: How the Ubiquity of Mobile Phones Is Unleashing an Entrepreneurial Revolution", Innovations: Technology, Governance, Globalization, vol. 7 no. 4, 2012.

[15] K. J. Sousa dan E. Oz, Management information systems, Nelson Education, 2014

[16] S. Cohen, D. Dori, dan U. de Haan, "A software system development life cycle model for improved stakeholders' communication and collaboration", International Journal of Computers Communications \& Control, vol. 5 no. 1, 2010.

[17] P. Isaias dan T. Issa, Information system development life cycle models. In High Level Models and Methodologies for Information Systems, New York: Springer, 2015.

[18] N. Hidayati dan Sismadi, "Application of Waterfall Model in Development of Work Training Acceptance System", INTENSIF, vol. 4 no. 1, 2020.

[19] A. Y. Aleryani, "Comparative Study between Data Flow Diagram and Use Case Diagram", International Journal of Scientific and Research Publications, vol. 6 no. 3, 2016.

[20] B. Dathan dan S. Ramnath, The Unified Modelling Language. In Object-Oriented Analysis, Design and Implementation, 2015, Springer, Cham.

[21] R.S. Pressman, Software Engineering Seventh Ed. McGraw Hill, 2010.

[22] P. Gelu, R. Sarno, dan D. Siahaan, "Requirements Association Extraction based on Use Case Diagram". Lontar Komputer, vol. 9 no. 1, 2018.

[23] A. D. Herlambang, A. Rachmadi, K. Utami, R. I. Hakim, dan N. Rohmah, "Pengembangan Fitur E-Matur dengan V-Model sebagai Alat Pengaduan Publik untuk Website Badan Kepegawaian Negara", Jurnal Teknologi Informasi dan Ilmu Komputer (JTIIK), vol. 6 no. 5, pp. 467-474, 2019.

[24] M. R. Fachrizal, J. C. Wibawa, and Z. Afifah, "Web-Based Project Management Information System in Construction Projects," IOP Conference Series: Materials Science Engineering, vol. 879, no. 1, 2020, doi: 10.1088/1757-899X/879/1/012064.

[25] V. Vukovic, J. Djurkovic, M. Sakal, dan L. Rakovic, "An Empirical Investigation of Software Testing Methods and Techniques in the Province of Vojvodina", Technički Vjesnik, vol. 27 no. 3, pp. 687-696, 2020.

[26] A. I. Melliana, and Nurgiyatna, "Sistem Informasi Arsip Surat Pada SMA Negeri 2 Sukoharjo Menggunakan Framework Codeigniter", Jurnal Pendidikan dan Teknologi Indonesia (JPTI), vol. 1 no. 4, pp. 141-149, 2021.

[27] V. Repa, "Object-Oriented Analysis with Data Flow Diagram", Information Systems Development, pp. 419-430, 2013. 